\title{
Quantification of soil loss in various lithological areas of the western Middle Atlas Central: application to the Ras-EIma, Tamelalet and Sebab watershed (Tigrigra watershed, Morocco)
}

\author{
Hassan Achiban ${ }^{1, *}$ Ali Taous ${ }^{1}$, Ismail El-Khantoury ${ }^{1}$, Mohamed El Mderssa ${ }^{2}$, Ali \\ Amechrouq $^{3}$ \\ ${ }^{1}$ Laboratory for Geo-Environmental Analysis, Planning - DD, Sidi Mohammed Ben Abdellah \\ University - Fez. \\ ${ }^{2}$ Laboratory of Soil Microbiology and Environment, Moulay Ismail University, Meknes. \\ ${ }^{3}$ Laboratory of Molecular Chemistry and Natural Substance, Moulay Ismail University, Meknes
}

\begin{abstract}
The present study proposes to evaluate the extent of erosion according to the lithology in three sub-watersheds (Ras Elma, Sebab and Tamelalet) belonging to the Tigrigra basin and evolving in humid climatic context. The methodology adopts the revised universal soil loss equation (RUSLE). The results obtained make it possible to establish erosion class maps via GIS. A clear spatial difference in soil loss is observed, between the three sub-basins and in proportion to the lithology: on average 42.15 t/ha/year on Paleozoic schistose soils, against 17.06 t/ha/year on carbonate substrates Mesozoic and $8.46 \mathrm{t} / \mathrm{ha} / \mathrm{year}$ on quaternary basalts. Correlations between soil loss and RUSLE factors are established. Soil infiltration regimes on different substrates are studied.
\end{abstract}

\section{Introduction}

Water erosion is the main factor in the degradation of the edaphic resource. It has become a major environmental concern, and its consequences are well felt in soil loss, ecosystems and siltation of dam reservoirs. Several models for predicting potential erosion, such as long-term models and empirical models at the scale of a watershed or plot have been developed in recent decades. The Revised Universal Soil Loss Equation (RUSLE) has become the most widely used method because it can be applied in many situations, even in topographically complex landscapes [1].

By adapting the above method, the present study focuses on the evaluation of potential soil losses in three sub-catchments belonging to the Tigrigra basin in the Azrou region (Fig. 1). In fact, the studied sub-basins (Ras Elma, Sebab, Tamelalet) evolve under relatively similar climatic-ecological conditions, but their lithology is variable, which influences the process of soil loss.

\footnotetext{
Corresponding address: hassan.achiban@usmba.ac.ma
} 
It is recalled that the watershed of the wadi Tigrigra is located astride the limestone plateau of the central Middle Atlas and the central Hercynian schist massif. The limestone plateau is composed of dolomite (lower Lias), limestone and marly limestone (Middle Lias). The ensemble is based on the saline red clays and doleritic basalt of the Triassic [2], which appear along structural and unconformity on the mainly schistose substratum, with some quartzite and sandstone beds [3]. The limestone plateau is pierced by Plio-Quaternary volcanoes [4] having emitted basalts which cover large areas in the Tigrigra Valley.

The forest cover of the Tigrigra watershed is very diversified, with a dominance of Atlas cedar (Cedrus atlantica) which occupies $49 \%$ of the forest, the holm oak (Quercus rotundifolia) covers $35 \%$ of the forest. Quercus canariensis and secondary species occupy $11.01 \%$ of the forest area of the watershed. In the end, reforestation with Cedrus atlantica, Pinus halepensis, Cupressus arizonica and Populus alba and nigra occupies $4.99 \%$ of the total area of the forest.

The climate of the study area is Mediterranean with a wet and cold winter, which often records heavy snowfall, while the summer is dry and hot. The seasonal distribution of rainfall is: W.S.A.S (Winter, Spring, Autumn, Summer) where the maximum is recorded during winter and spring.

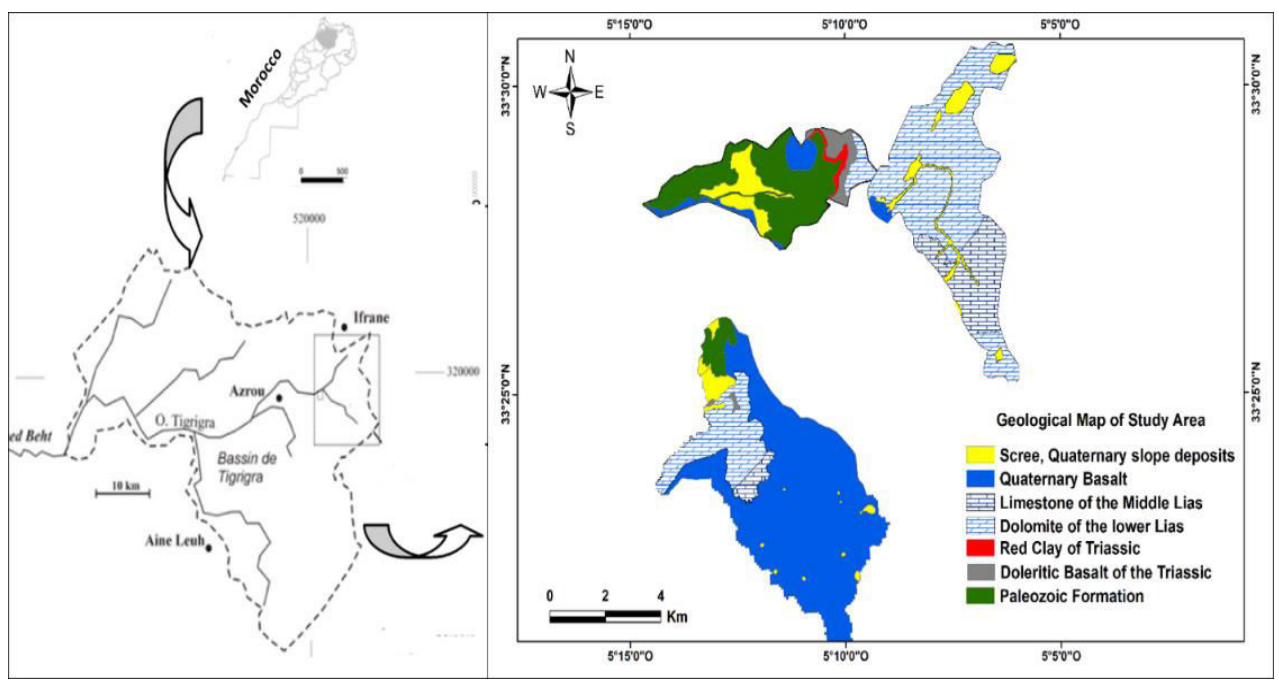

Fig. 1. Geological Map of Study Area

\section{Materials and methods}

\subsection{Sources and Materials}

The methodology adopted for the evaluation of water erosion in the sub-watersheds studied is founded on the spatialization and cross-referencing of altimetric, topographic, climatic, forest and geological data. It was based on a digital elevation model (DEM) of 20 $\mathrm{m}$ resolution, topographic maps at 1: 50,000 (Azrou and Ifrane sheets), the forest inventory map of the Azrou forest and Rainfall data over 30 years from six weather stations in the study area. The lithological characterization of the three watersheds was based on the Azrou 1: 50,000 and Elhajeb 1: 100,000 geological maps.

The particle size analysis of the developed soils on the various lithological facies as well as their contents in organic matter was determined experimentally in the laboratory. The permeability tests of the different soils were carried out by means of a disk infiltrometer.

\subsection{Methodological approach}


The erosion quantification is relying on the application of the USLE soil loss equation established by [5] and modified by [6]. This model makes it possible to quantify the sheet erosion, through the implication of the different parameters according to the relation:

$\mathrm{A}=\mathrm{R}$. K. LS. C. P (A, is the annual rate of soil loss expressed in $\mathrm{t} / \mathrm{ha} / \mathrm{yr}$

$\mathbf{R}$ is the rainfall erosivity factor, calculated for each station by the relation of [7]:

$$
\operatorname{Ln} R=1.74 \log \Sigma\left(P i^{2} / P\right)+1.29
$$

with $\mathrm{Pi}=$ the average of the monthly precipitations and $\mathrm{P}=$ Average of the annual precipitations). The results obtained were interpolated by means of GIS on the three basins.

$\mathbf{K}$ is the erodibility of soils. Not only does it take into account the particle size and the percentage of organic matter, but also the soil structure and its permeability class. Its calculation was hinged on the granulometric analyses outcomes, in addition to the organic matter of 51 samples of the first horizons of soils results. The sampling sites were chosen based on the lithological variation and the nature of the land cover. The formula used to calculate erodibility is that of [8]:

$$
100 K=2.1 * 10-4 * M 1.14 *(12-a)+3.25 *(b-2)+2.5 *(c-3)
$$

with $\mathrm{M}$ is the product of the percentage of silt between 0.1 and $0.002 \mathrm{~mm}$ by the percentage of all that is not clay; $a$ is the percentage of organic matter; $b$ is the soil structure code used in the classification; c expresses the class of permeability of the profile.

LS is a dimensionless factor which represents the inclination (S in \%) and the length of slope ( $\mathrm{L}$ in $\mathrm{m}$ ), it was calculated by the formula of [8]:

$$
L S=(L / 22,13)^{m *}(0.065+0.045 * S+0.065 * S 2)
$$

where $\mathrm{m}$ is a parameter such that $\mathrm{m}=0.5$ if the slope is $>5 \%, \mathrm{~m}=0.4$ if the slope is 3.5 to $4.5 \%, \mathrm{~m}=0.3$ if the slope is 1 to $3 \%$ and $\mathrm{m}=0.2$ if the slope is $<1 \%$. Topographic data were obtained from GIS treatments of the $20 \mathrm{~m}$ resolution digital terrain model covering the study area.

$\mathbf{C}$ is a dimensionless factor that represents the effect of vegetation cover; its determination is grounded on the density and height of the strata. It has been mapped from the classification of strata on the forest inventory map of the study area; based on the Wischmeier \& Smith tables which give pre-established values according to the nature of the plant occupation of the soil.

$\mathbf{P}$ is also a dimensionless factor that takes into account cultural techniques and antierosion practices. For the study area, these practices are almost absent and the factor $\mathrm{P}$ has taken the value 1 .

\section{Results and discussion}

The application of the Wischmeier \& Smith formula [8] through the cross-mapping of the five main factors involved in soil water erosion yielded soil loss maps expressed in t/ha/yr. at all points of the three basins of Ras Elma, Tamelalet and Sebab (Fig. 2). For the purposes of map readability and to keep more detail, the different values have been grouped into five classes that have consistent values of the USLE factors. The classification of erosion takes into account the soil tolerance threshold which is defined as the balanced earth loss with soil formation through rock alteration and which is assumed to have no negative impact on soil productivity. This tolerance varies from 1 to $12 \mathrm{t} / \mathrm{ha} / \mathrm{year}$ depending on the climate, type of rock and soil thickness [6]. The threshold considered in this study is equal to $7 \mathrm{t} / \mathrm{ha} / \mathrm{yr}$, value used in other erosion studies in Prerif Mountain [9], [10] and in the Beht Basin [11]. Above $20 \mathrm{t} / \mathrm{ha} /$ year, the loss is high and soils are much degraded [9]. However, the small losses below the threshold of tolerance of Wischmeier $(<7 \mathrm{t} / \mathrm{ha} /$ year $)$ at 
the level of the three basins Sebab, Ras Elma and Tamelalet concern respectively $76,2 \%$, $51,5 \%$ and $49,8 \%$, while the strong erosion exceeding $20 \mathrm{t} / \mathrm{ha} /$ year affects only $9.8 \%$ and $12.1 \%$ respectively for the basins of Sebab and Ras Elma which are dominated by carbonate formations and basaltic formations, compared to $36.3 \%$ for the sub-basin of Tamelalet which drains the mainly schistose terrains of the western Paleozoic Meseta (Central Morocco).

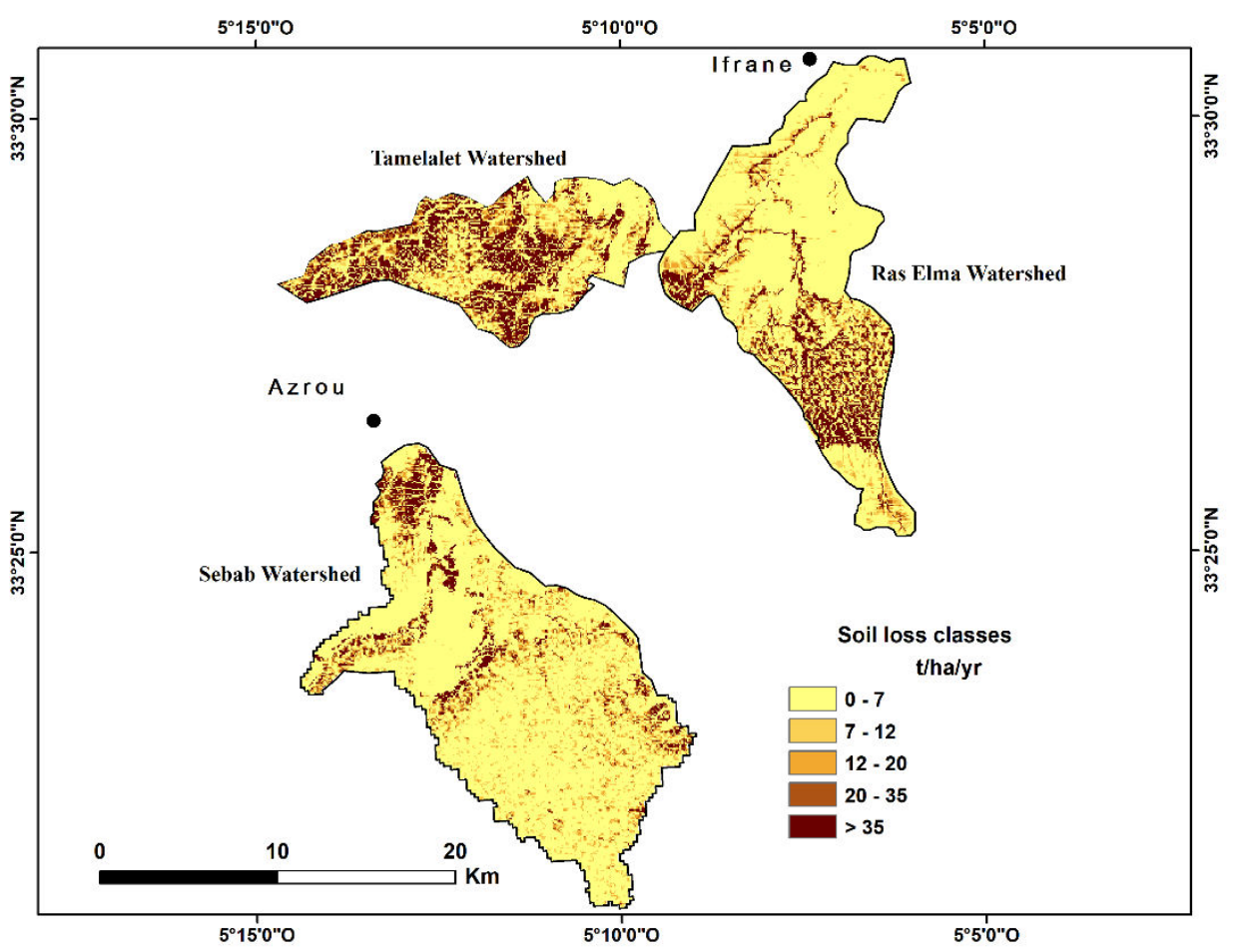

Fig. 2. Map of the water erosion of the basins of Sebab, Ras Elma and Tamelalet

The distribution of soil loss classes according to the lithological nature of the Sebab sub-basin shows that $52 \%$ of the formations of the Upper Ordovician undergo strong and very strong erosions whereas $80 \%$ of Quaternary basalts, which cover more than $74 \%$ of the basin, are subject to erosion below the tolerance threshold of Wischmeier (Tab. 1). In the predominantly carbonate-dominated Ras Elma watershed, $40 \%$ of the limestones of the Middle Lias undergo strong erosion compared to only $7 \%$ in the Lower Lias dolomite (Tab. 2).

Table 1. Distribution of soil loss classes according to the lithological nature (Sebab Watershed)

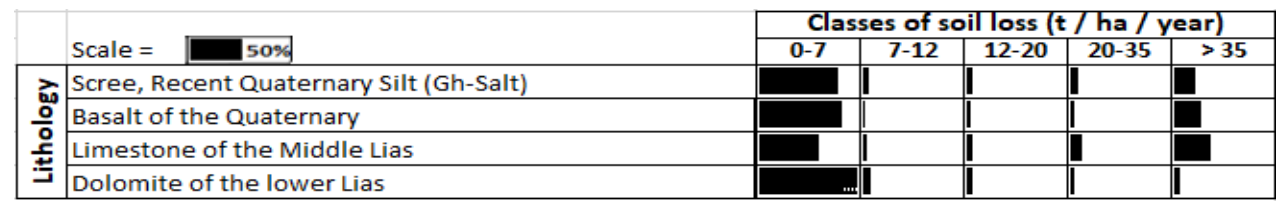

Table 2. Distribution of soil loss classes according to the lithological nature (Ras Elma Watershed) 


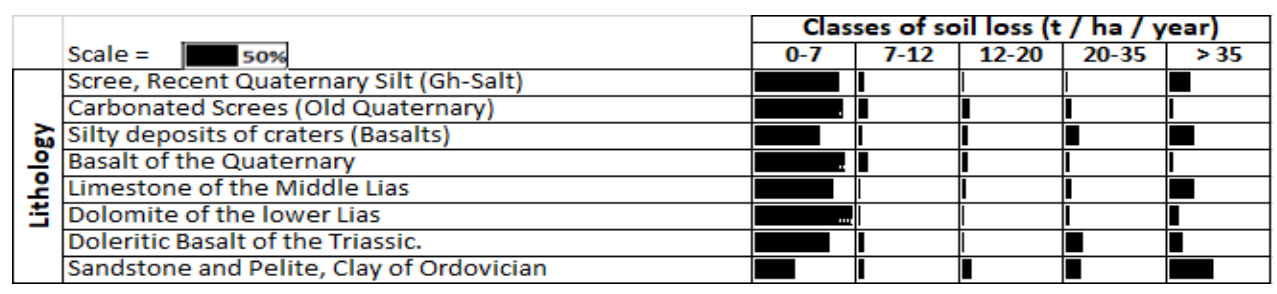

In the Tamelalet sub-basin, Silurian, Middle Devonian and Upper Viséan shales are the most affected by erosion, with $67 \%, 64 \%$ and $55 \%$ respectively of their areas. The Secondary formations are the least affected by the strong erosion: $95 \%$ of Triassic basalts show an erosion of less than $7 \mathrm{t} / \mathrm{ha} /$ year, as do $75 \%$ of Lower Lias dolomites and $54 \%$ of Quaternary basalts (Tab. 3).

Table 3. Distribution of soil loss classes according to the lithological nature (Tamelalet Watershed)

\begin{tabular}{|c|c|c|c|c|c|c|}
\hline & & & es of $s$ & |loss & ha / & \\
\hline & Scale $=\square 50 \%$ & $0-7$ & $7-12$ & $12-20$ & $20-35$ & $>35$ \\
\hline & Scree, Quaternary slope deposits & & & & & \\
\hline & Scree, Silty terrace of the late Quaternary & & & & & \\
\hline & Silty deposits of Quaternary & & & 1 & & \\
\hline & Basalt of the Quaternary & & & I & & \\
\hline & Dolomite of the Lias & & & & & \\
\hline & Doleritic Basalt of Triassic & & & & & \\
\hline & Red clay of the Triassic & & & & & \\
\hline & Black silty shales, fine sandstone & & & & & \\
\hline an & Black shales, Conglomerate, nodule schist, sandstone & & & 1 & & \\
\hline$\overline{0}$ & Black calcareous shales, lenticular conglomerates, sandstone & & & & & \\
\hline \pm & Shale-limestone & & & & & \\
\hline & Schists Clay, silty, calcareous gray with sandstone & & & & & \\
\hline & Shale-limestone & & & & & \\
\hline & Sandstone limestones, Shale-Limestone & & & 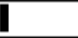 & ב & \\
\hline & Limestone crinoids, Silts and sandstones & & & 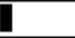 & $\Xi$ & \\
\hline & Hard shales and pale gray schistous pelites & & & ! & 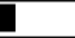 & \\
\hline & microconglomerate clays, quartzite, sandstone and pelite & & & & & \\
\hline & microconglomerate clays, quartzite, sandstone and pelite & & & ] & & \\
\hline & micaceous black shales with aggregates of muscovite and chlorite & & & 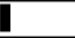 & & \\
\hline
\end{tabular}

When considering the average losses according to the lithology, the results obtained by the empirical models show that the Paleozoic metamorphic formations are the most affected by the strong erosion, with an average of $47.3 \mathrm{t} / \mathrm{ha}$ /year; they are followed by the Triassic clays $(36.6 \mathrm{t} / \mathrm{ha} /$ year $)$, then by the limestones of the middle Lias (26 t/ha/year); while Quaternary basalts and Lower Lias dolomite are the least influenced, with mean values of $10.3 \mathrm{t} / \mathrm{ha} /$ year and $6.4 \mathrm{t} / \mathrm{ha} /$ year, respectively (Fig. 3). 


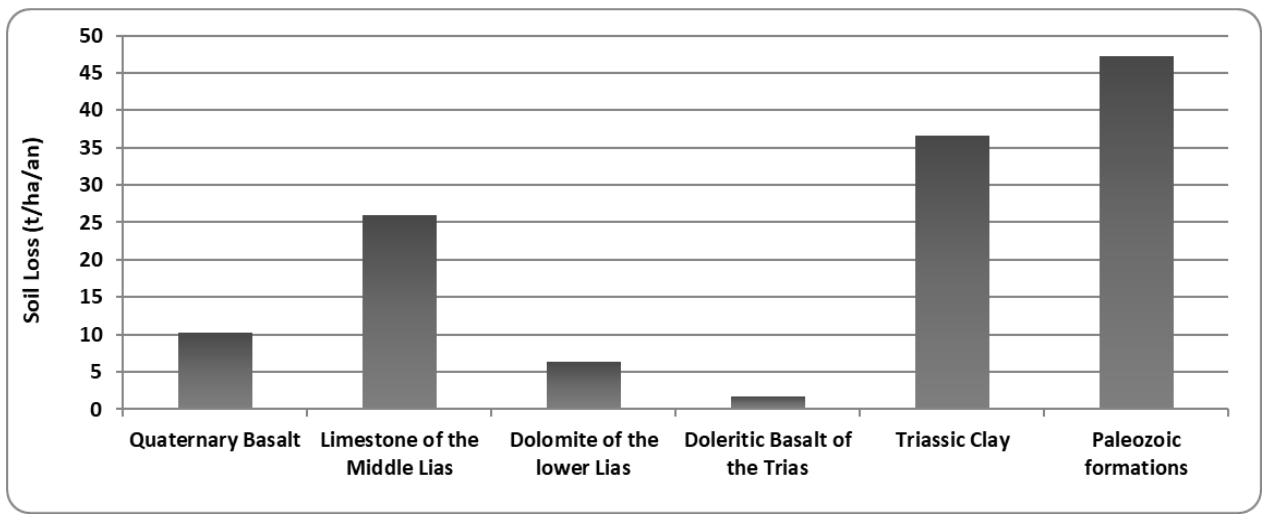

Fig. 3. Mean loss in $\mathrm{t} / \mathrm{ha} / \mathrm{yr}$ by lithologic formation

The distribution of soil losses in the three sub-basins is unequal for the same lithological formations because of the spatial variability of the various factors considered. To demonstrate the influence of each factor, the mean loss results were correlated with the values for each factor of the Wischmeier equation, using the Pearson (R) correlation test (Fig. 4). The results obtained show that all the factors act in the process of soil loss in the three sub-basins, but with a stronger influence of the K and LS factors. Thus, at the scale of the Tamelalet sub-basin, the correlation coefficient between the soil loss and these two factors is respectively 0.51 and 0.48 , against 0.17 and 0.36 respectively when correlated with climatic aggressiveness $(\mathrm{R})$ and vegetation cover $(\mathrm{C})$.

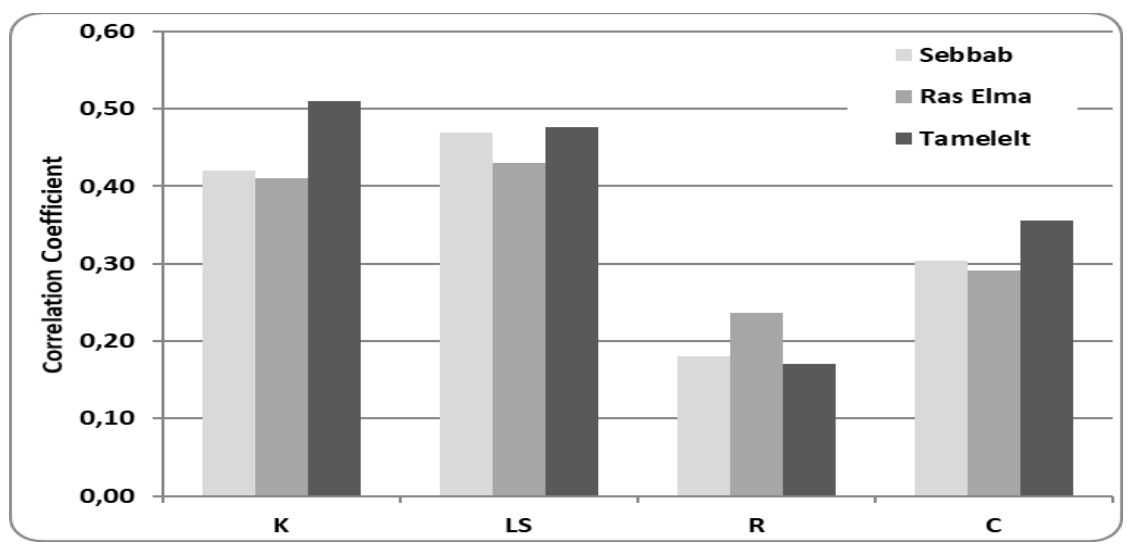

Fig. 4. Correlation between Soil Loss and RUSLE Factors

Various soil infiltration tests were performed using a disk infiltrometer at each lithological facies of the study area. The results obtained are shown in the figure 5 . These results show that the doleritic basalt of the Triassic has a high infiltration capacity exceeding on average $26 * 10^{-2} \mathrm{~m} / \mathrm{s}$, followed by Lower Lias dolomites $\left(19.4 * 10^{-2} \mathrm{~mm} / \mathrm{s}\right)$ and Quaternary basalts $\left(14.78^{*} 10^{-2} \mathrm{~mm} / \mathrm{s}\right)$. In contrast, Paleozoic schists have the lowest values $\left(2.59 * 10^{-3} \mathrm{~mm} / \mathrm{s}\right)$, followed by Triassic red clays $\left(1.8^{*} 10^{-2} \mathrm{~mm} / \mathrm{s}\right)$ and limestone of Middle Lias $\left(2.96^{*} 10^{-2} \mathrm{~mm} / \mathrm{s}\right)$. Thus, the low infiltration of certain formations, associated with the topographic factor, generates more runoff which causes the detachment and the displacement of particles of the surface of the ground. 


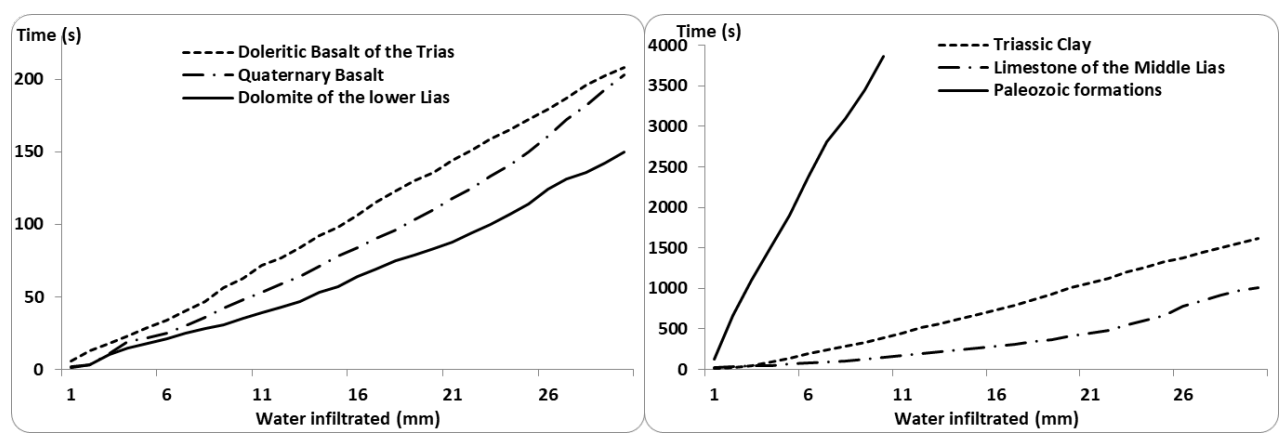

Fig. 5. Infiltration regime versus time for different soil types

In general, the specific degradation in the study area is lower than that obtained in the Rif Mountains which provide more than $60 \%$ of the sediments mobilized each year in the country [12]. In fact, if the results obtained in our case indicate values varying according to the lithology between $47.3 \mathrm{t} / \mathrm{ha} / \mathrm{yr}$ and $6.4 \mathrm{t} / \mathrm{ha} / \mathrm{yr}$, the average soil loss in the Rif is 62.7 $\mathrm{t} / \mathrm{ha} / \mathrm{yr}$ in the Oued Haricha watershed [13], $61 \mathrm{t} / \mathrm{ha} / \mathrm{yr}$ in the Oued Tlata watershed [14] and $55.3 \mathrm{t} / \mathrm{ha} / \mathrm{yr}$ in the watershed of Oued Boussouab [9]

\section{Conclusion}

This paper presents the results of applying the Revised Universal Soil Loss Equation using a geographic information system. At the end of this study, it can be concluded that water erosion is the main source of degradation of soil capital at the level of studied watersheds. In addition, it has been possible to establish a soil loss map, taking into account the various factors at the origin of this phenomenon. This map highlights the dominance of high and very high loss classes in the Paleozoic formations that dominate the Tamelalet basin, followed by Lias limestone in the Ras Elma basin. The study made it possible to spotlight the correlation between soil loss and the factors involved in erosion as a function of the lithologies in the basins studied; it also allowed us to evaluate the infiltration regimes of the different types of soils of the studied basins. All these results make it possible to define the areas where the anti-erosive intervention is urgent.

\section{References}

1. P. Desmet, G. Govers, J. Geogr. Inf. Syst., 10, pp. 311 - 331, (1996)

2. G. Colo, Contribution à l'étude du Jurassique du Moyen Atlas septentrional. (Notes et Mémoires du Service géologique du Maroc, 139, 1961)

3. A. Benslimane, Étude hydrogéologique du bassin de Tigrigra ; apport de la géoélectrique a la reconnaissance des potentialités hydriques dans les formations basaltiques subaffleurantes, Thèse de doctorat (Faculté des Sciences Meknès), (2005)

4. G. Beaudet, Le plateau central marocain et ses bordures : étude géomorphologique (Rabat, 1969)

5. WH. Wischmeier, Journal Soil and Water Conservation., 31, pp. 5-9, (1976)

6. KG. Renard, GR. Foster, GA. Weesies, DK. Mccool, Predicting soil erosion by water. A guide to conservation planning with the revised universal soil loss equation (RUSLE). (Agric. Handbook 703. US Govt Print Office, Washington, DC, 1996)

7. A. Rango, H.M.J. Arnoldus, Cahiers techniques de la FAO., pp. 1-11, (1987)

8. WH. Wischmeier, DD. Smith, Predicting rainfall erosion losses - a guide to conservation planning. (Agriculture Handbook No. 537. US Department of Agriculture Science and Education Administration, Washington, DC, USA, 1978) 
9. A. Sadiki, S. Bouhlassa, L. Auajjar, A. Faleh, J. Macaire, bulletin de l'institut scientifique., 26, pp. 69-79, (2004)

10. A. El Garouani, H. Chen, L. Lewis, A. Tribak, M. Abahrour, Revue Télédétection., vol. 8, 3, pp. 193-201, (2008)

11. DREF- Nord-ouest, Étude d'aménagement du bassin versant d'Oued Beht en amont du barrage El Kansera, (Fès, 2007)

12. B. Heusch, Ann. Recherche Forestière du Maroc., 12, pp. 9-176, (1970)

13. M. Tahiri, H. Tabyaoui, A. Tahiri, H. El Hadi, F. El Hammichi, M. Achab, Journal of Geoscience and Environment Protection., 4, pp. 107-119, (2016)

14. A. Tribak, A. El Garouani, M. Abahrour, Revue Télédétection., vol. 20, 4, pp. 333-337, (2009) 